\title{
Livonian in the 21st century
}

Le live au XXI ${ }^{e}$ siècle

Lìbiešu valoda 21. gadsimtā

\section{Valts Ernštreits}

\section{OpenEdition}

\section{Journals}

Édition électronique

URL : https://journals.openedition.org/efo/675

DOI : 10.4000/efo.675

ISSN : 2275-1947

\section{Éditeur}

INALCO

Édition imprimée

Date de publication : 1 décembre 2012

ISBN : 978-2-343-02592-6

ISSN : 0071-2051

\section{Référence électronique}

Valts Ernštreits, «Livonian in the 21st century », Études finno-ougriennes [En ligne], 44 | 2012, mis en ligne le 12 février 2014, consulté le 10 juillet 2021. URL : http://journals.openedition.org/efo/675 ; DOI https://doi.org/10.4000/efo.675

Ce document a été généré automatiquement le 10 juillet 2021.

\section{(c) (7) (8)}

Études finno-ougriennes est mis à disposition selon les termes de la Licence Creative Commons Attribution - Pas d'Utilisation Commerciale 4.0 International. 


\title{
Livonian in the 21st century
}

\author{
Le live au XXI' siècle \\ Lỉbiešu valoda 21. gadsimtā
}

Valts Ernštreits

1 Livonian (Livõ kèl, also rāndakêl) is the language of Latvia's indigenous (autochthonous) people, which is one of the smallest of the EU languages recorded in the UNESCO Red Book of Languages (UNESCO online). Genealogically it belongs to the Finno-Ugric subgroup and Baltic-Finnish group of the Uralic languages. Apart from Livonian this group also comprises the Estonian, Finnish, Karelian, Veps, Izhor and Votic languages (Libiešu, online). In earlier times Livonians inhabited both sides of the Gulf of Riga, including vast areas around Latvia's present capital - Riga. However, in the 20th century the last Livonian-speaking settlements could be found on the North Courland coast, across from the Estonian island of Saaremaa.

\section{The use of the Livonian language and the dynamics of the language situation}

2 The fusion of the Livonians and Latvians in Vidzeme, as well as their language shift was achieved in the second third of the 19th century (Blumberga 2010, p. 26). In Courland these processes took a longer period of time. Looking back to a more recent past, the Livonian community of Courland has been bilingual since the First World War.

3 The main cause of bilingualism is the fact that Livonian has never been the working language of an establishment, school or church but was used only by families, in social life and in different cultural activities.

4 In the early 1920s there was an effort to establish a Livonian municipality in North Courland villages inhabited by Livonians. Had this idea succeeded, and an administrative territorial unit using the Livonian language for record-keeping and communication along with Latvian been created, perhaps the present situation would be more favourable for the development of Livonian. However, Livonian would still be at risk today. 


\section{Native speakers}

Since after the Second World War Livonians were scattered around Latvia and the world. During the 1950s, the USSR enacted its border-line regime in the Livonian villages along the North Courland coast, meaning that transmission of Livonian to the next generations almost completely stopped. That meant that the bilingual Livonian community gradually developed into a Latvian-speaking community, and Livonian in household communication was replaced by Latvian, with only the older generation, born between the First and Second World Wars or earlier, retaining the language skills.

6 The number of Livonian speakers, estimated at about 500-600 people after the Second World War, remained unchanged while this generation lived. There were only a few cases when the language was passed on to descendants (Ernštreits online). Thus, it should be concluded that Livonian is no longer used in everyday life and in families. The last people who used Livonian in their household communication were the family of Viktors Bertholds and his wife Marta. Viktor died on 28 February 2009.

7 At present Livonian is the native tongue (the first language) of only one person Grizelda Kristina (born in Vaid village, 1910) who lives in Canada, Ontario. Almost all of the native Livonian speakers died in the last decade. The last one in Latvia was Erna Vanaga, who died on 16 February 2010.

\section{Other speakers of Livonian}

8 Today, along with the native speakers there are Livonian descendants who have fully mastered the language, from their grand-parents, in courses, or through self-tuition. They can communicate, as their language skills in most cases are evaluated as $\mathrm{B} 1^{1}$, with some people of even higher level. There are about fifteen people in this group of language users ${ }^{2}$. Unfortunately, as the language cannot be actively used, knowledge of it is unstable, in many cases it gets lost, and communication among the few remaining Livonians occurs mostly in Latvian. The fact that the native language of these people is Latvian and its use in mutual communication is habitual means that using Latvian, unlike the rare use of Livonian, provides possibilities of fuller expression and more precise perception.

9 In the last decade the number of Livonian speakers has slightly increased due to users and other interested people, of whom only one part have Livonian roots. This group consists of about ten people and their knowledge is basically assessed as A2/B1, in some cases a little higher. This user group together with a small number of the abovementioned people constitute a confined cluster which, as they declare, is trying to use the Livonian language in communication. They use www.draugiem.lv, Skype and various other arrangements for their activities. Watching the development of this group, especially the language acquisition and use, it may be concluded that it has a tendency to be isolated from the rest of the Livonian language users and to disregard the existing trends and past experience. Since the cluster consists mainly of young people up to ca. 25 years of age, this tendency can be most likely explained as a need for selfidentification, stressing this particular identity and group affiliation with the specific maximalism of the given age group. 

or A2 has increased. And to a great extent this was due to state-supported language training activities and active promotion of Livonian language and culture during recent years. In general, rating optimistically, we may consider that the number of A1 and A2 level speakers increased for approximately 50 people and today it has reached $150 \mathrm{~A} 1$ and A2 speakers in total, including people who, as in the previous case, have no Livonian origin.

11 In addition to the abovementioned groups there is also a group of scientists and other people who are interested in Livonian culture, who utilize the Livonian language mainly for research purposes. Presently the group is ca. fifteen people with language skills ranging from level B1 to $\mathrm{C} 2$ and has grown in the last decade, as new Livonian researchers appeared in Estonia and Finland as well. The University of Tartu, with its traditions of language teaching and research as well as its promotional activities, has played an important role. Likewise, the number of emerging researchers who have mastered Livonian to A1 or A2 level at the training programmes of the Universities of Tartu, Helsinki, Latvia and the Latvian Academy of Culture has increased. In all the three states together, within five years, the total is approximately 60 A1 or A2 level Livonian speakers.

\section{The number of the Livonian language speakers}

Thus we can say that today there are about 40 people worldwide who can communicate (level B1 or higher skills) in Livonian, of whom only a half is of Livonian origin and only one is a native speaker. Optimistically judging there are up to $210 \mathrm{~A} 1$ and A2 level speakers.

13 Improvement of the economic situation in the 21st century has played its role as well if compared with mid- and the second half of the 1990s, as has the improved availability of language learning and terms of use. It can be noted that interest in Livonian is not rapidly growing among people of Livonian origin, but the number of language users has grown due to other users of the language for those living in Latvia and abroad.

\section{Acquisition of the language}

\section{Optional training of Livonian}

14 The tradition of optional teaching of Livonian can be found in the 1920 and 1930s when seven schools were functioning in the Livonian villages - in Mustānum (Melnsils), Kūolka (Kolka), Sānag (Saunags), Irē (Mazirbe), Sỉkrõg (Sīkrags), İra (Lielirbe) and Pizā (Miķețtornis). Since autumn 1923, Livonian was taught optionally in all the village schools, except in Mustānum. On average, one hundred pupils attended these classes annually and there were five Livonian teachers working - Kōrli Bernštein, Pētõr Damberg, MaŖt Lepste, Kōrli Stalte and his daughter Margarete Stalte (Blumberga 2006).

After the renewal of Latvian independence, Livonian language teaching was restarted. Beginning with autumn 1989 up to spring 1995, it was also taught at Sunday school in Riga, which was financed from the municipal budget. The first teacher was Kersti Boiko, later this function was taken over by Tenu Karma and Valda Marija Suvcāne. 
Sunday school in Riga ceased its existence due to lack of students (Šuvcāne 2006). After 1995, Livonian was for a while not taught systematically. However language courses were available from time to time both in Riga and in Courland.

During the last decade, Livonian teaching was once again implemented on a regular basis and not only in Riga and various places of Courland, but also in Vidzeme. To be more precise, it was taught in Riga, Ventspils, Dundaga, Kolka, Staicele and Pāle by the teachers Mārīte Zandberga, Zoja Sīle, Ērika Krautmane, Julgī Stalte, Dagmāra Ziemele, Jānis Mednis and others, but in recent years regular training has stopped once again mainly due to economic reasons.

It should, however, be admitted that it is difficult to make an overview of the attendance and the results of these courses, since no summaries are available, the participants were not registered and they did not receive any certificates, etc. It is somewhat hard to decide on the impact these courses have had on Livonian language acquisition in general.

In 2005, for example, training was characterized like this:

It is possible to acquire the basic level of the Livonian language in Riga, Staicele, Ventspils, Dundaga and Kūolka. There is no unified programme for such training and its regularity, teaching aids and number of participants varies. Most regularly it takes place in Riga - once a week (...) Participants are divided into two groups: one group without prior knowledge and the other with basic knowledge. There are approximately ten participants, none of whom consider themselves Livonians. (Ernštreits, online)

In addition to the courses which take place throughout the year, starting from the beginning of the 1990s annual (except for 2010 and 2012) camps dedicated to Livonian language and culture have been organized in Irē. Although these camps are mainly for children, there have been attempts (in 2006, 2007, 2008) to expand them as a $3 \times 3$ model, i.e. generation camps where children participate together with their parents and grandparents. In the aspect of language acquisition the biggest problem has been the large number of participants, which makes learning much more difficult. Apart from the participants' level of language skills, interests are very varied. In addition, most of these people have been learning Livonian only in the camps, so between camps the knowledge is mostly lost.

\section{Factors that influence the acquisition of language}

By evaluating Livonian language acquisition in the courses and camps, several fundamental problems can be ascertained. As there is a lack of teachers with good knowledge of Livonian, training in the courses and summer camps is led by people who have only basic language skills themselves and who have not studied language teaching methods. Although Livonian has already been taught for two decades in Latvia there is still no system created - no programmes, no teachers prepared and certified. As a result, every teacher teaches what he or she knows, although the participants attend the basic level several times without the opportunity to move to a higher level (Blumberga 2010, p. 24). However, there was an attempt to prepare teachers of the Livonian language in the reviewed period. In 2004 a series of seminars for teachers of Livonian language and culture was organized led by Dr. hist. Renāte Blumberga and $\mathrm{PhD}$ student of Tartu University Valts Ernštreits. 
of suitable teaching assistance is a separate problem. The textbooks currently available are either too complicated or not suitable for the acquisition of basic knowledge and therefore the teachers are forced to develop their own teaching material. In addition, in the present situation the teaching aids should include audio material as well, as the learners of Livonian have no possibility to stay in the language environment and to hear the original language. Thus, to learn pronunciation, for example, they often have to do with the teacher's explanation instead of hearing daily language patterns.

There have been attempts to solve this problem by creating various textbooks, but unfortunately these materials are generally still in manuscript form. The difficulties in preparing the teaching aids are caused by the previously mentioned diverse levels of language skills and age categories of the participants in courses and camps, and also by the explicit lack of grammatical standards. It seems that there were attempts to systematize teaching already in 2005 or 2006 by creating unified programmes (Virtmane online), however, this material has not been publicly distributed and the teachers have not used these programmes in practice.

Despite these difficulties, it can be concluded that the Livonian courses perform an outstanding function, serving as a meeting place where in addition to the improvement of language skills people can discuss various topical questions and learn a lot about different aspects of Livonian culture and history. This explains the regular involvement of many participants in language learning.

\section{Camps for the improvement of Livonian language skills}

As Livonian has lost its use in everyday life, certain measures have been taken to maintain and improve the proficiency level of those who can communicate in Livonian. In summer 1998, the first Livonian speakers' camp, organized by the Livonian Culture centre (LCC), took place in Vaid village. In summer 2005, another camp was arranged in Irē.

To encourage the use of Livonian in communication, the members of the International Livonian Friends' Society who do not speak Latvian were invited as well. Since then these camps have taken place every year - in 2006 in Sikrõg, in 2007 and 2008 in Pizā. At the beginning of 2010, a seminar in Kuoštrõg (Košrags), supported by Tartu University, was organized, actually replacing the missing speakers' camp of 2009. The youth section of the Livonian Union (LU) and the Livonian foundation (LF) have tried to implement similar principles in camps which took place, respectively, in Mazsalaca in 2008 and on Hiiumaa island in 2010.

During the 2005 event, the so-called conversation group was created by the LCC and it functioned once a month from autumn 2005 until the end of the first half of 2006. It was created for the improvement of overall Livonian skills, but focused mainly on the maintenance of conversational skills, and was attended by an average of ten people who spoke, read, listened to and translated texts. Teachers of the basic level were also involved. 


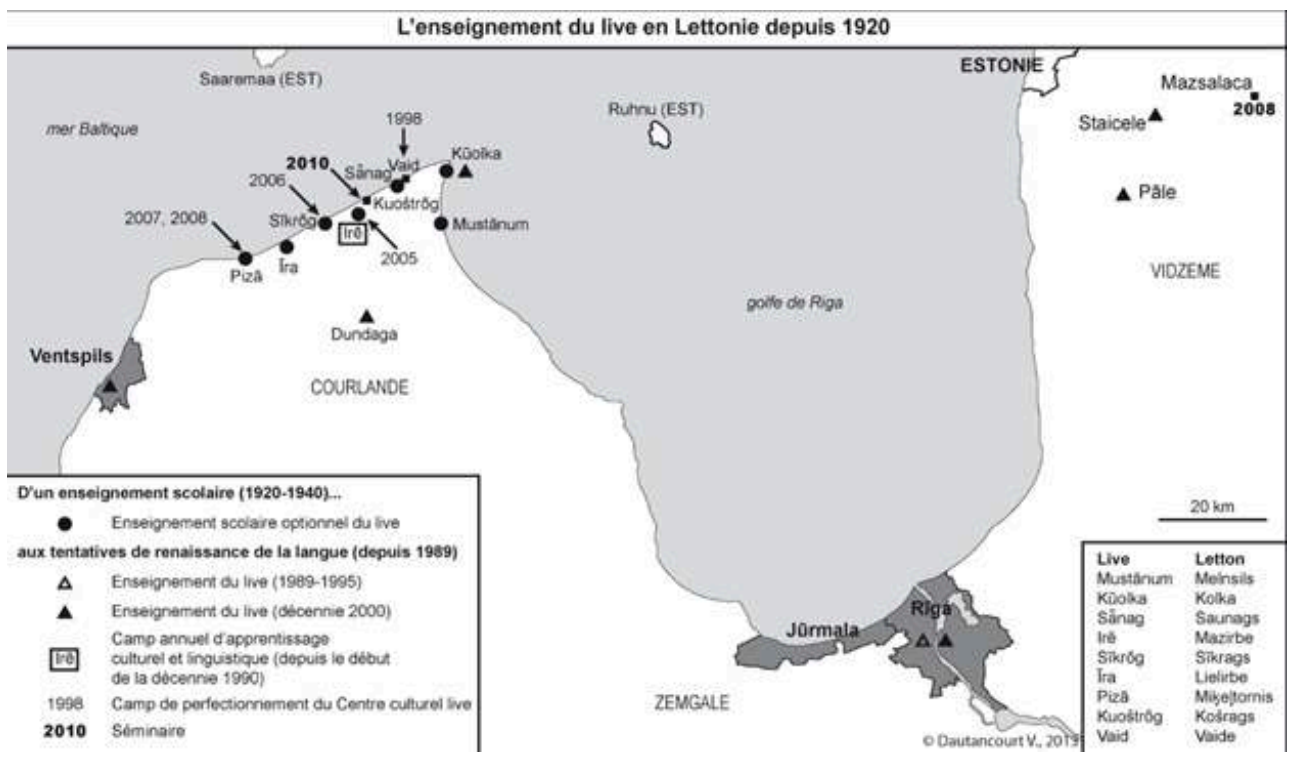

\section{Livonian in higher education institutions}

At the level of higher education, Livonian has been studied and investigated for more than seventy years. During this time it has been possible to study it in Finland (University of Helsinki, Turku University), in Estonia (Tartu University), Hungary (Lorand Eötvös Budapest University) and in Latvia (University of Latvia, Latvian Academy of (ulture) and other higher education institutions.

In the last decade it was possible to master the Livonian language at four higher education institutions: the University of Tartu (Tuuli Tuisk and Tiit-Rein Viitso); The Faculty of Humanities, University of Latvia (Valts Ernštreits and Ërika Krautmane); the Latvian Academy of Culture (Ërika Krautmane); the University of Helsinki (Riho Grünthal).

The University of Tartu and the University of Helsinki offer Livonian primarily as an optional course and as an additional subject of the Uralic language group, particularly for research into Baltic and Finnish languages. Livonian has never been included in post-graduate programmes in full scale but provides an insight only into the language, its grammar and history. Thus the students may retain and develop the acquired knowledge and skills only if they are closely involved in the research work into Livonian.

It has been possible to study Livonian as a mandatory course in the Finno-Ugric study programme at the Faculty of Humanities, University of Latvia (initially, Faculty of Modern Languages). As these students are mostly those who are specializing in Finnish or Estonian, the acquisition of Livonian is secondary again, and during the whole period of existence of this programme not a single researcher specializing in Livonian has ever appeared. Perhaps it would be more useful to promote and offer the Livonian language as an optional subject to all the students of the University of Latvia, thus giving the researchers of other fields or students of Livonian descent studying in other faculties (as well as other interested students) the opportunity to use this language. 
It must be added here that higher education institutions and scientists working in them have been the most important driving force of the research and development of the Livonian language. Without their active participation most of the knowledge about the language would have failed to reach the present world. We must thank them also for their direct and indirect participation in the creation and development of the literary Livonian as well as for the extensively documented (various editions, manuscripts, records) Livonian language.

\section{Publications in Livonian}

It can be said that today the tradition of Livonian is indeed continued not so much by oral conversations, but by written sources. Therefore different publications have also an important role in preserving Livonian in the 21st century. During the last decade a great effort has been made to compile both language materials and means of communication.

The 21st century's most important source for the study and research of Livonian is the Livonian-Estonian-Latvian dictionary (Viitso, Ernštreits 2012) published in 2012. This is the biggest Livonian dictionary ever and includes many language examples, using at the same time literary Livonian orthography and offering much grammar, offering those who want to study Livonian plenty of possibilities. An electronic version of this dictionary is also under preparation.

In the last decade, three previously unknown manuscripts of great importance for the Livonian language were found in the Estonian archives. They are: the album Life of the Livonians compiled by P. Dambergs (Livõd 2007), the manuscript of the Livonian ABC (Stalte 2011), compiled by K. Stalte in 1936 and found by the LCS researcher R. Blumberga, and the manuscript "Terms of the Livonian language grammar" compiled by O. Loorits around 1923, which includes Livonian grammar for school needs. These manuscripts, along with other publications, have been useful as teaching materials. In addition, other publications supporting language studies have been published during the recent decades, the most important being the tutorial of the Livonian language (Boiko 2000) supplemented by a CD with recordings of Grizelda KristiN.

In the field of digital media, the www.livones.net ${ }^{3}$ portal should be mentioned as the most important. Originally, the site was intended to offer basic information about the Livonians - their language, history, symbols, traditional culture arts, literature, etc., in three languages (Latvian, Livonian and English). Today this site comprises the biggest public collection of the modern Livonian texts available on the Internet. While the newspaper Livli was issued more and more rarely, the portal took over the function to inform the society, thus becoming the only publicly available source dedicated to Livonian topics.

\section{Language standardization and planning}

The history of literary Livonian is more than 150 years old. The rapid decline of the number of native (first language) speakers during recent decades has caused changes in written Livonian resulting in a need for adjustments: a closer connection of spelling and pronunciation has been required (Ernštreits 2010). 

founded. The record-keeping and working language in the interwar period (in the 1920s-1930s) was Livonian. After the renewal of the organization in $1989^{4}$, Latvian became its working and record-keeping language. This was caused by the lack of language skills of both the leadership and the majority of its members. The Livonian language mainly played a representative role in festive meetings. ceremony traditionally begins with one or two speeches in Livonian. In the period from 2004 to 2010 essential changes could be observed in the use of Livonian in this biggest event dedicated to the language - the number of speeches in Livonian significantly declined in the later years, while in the very last years it was only the chairman of the ILFS, Professor Emeritus of the University of Tartu Tiit-Rein Viitso, who spoke in Livonian.

\section{The Livonian Foundation 2009}

The situation seemed to slightly improve in 2009, when, supported by the Livonian Union, the public organization The Livonian Foundation (LF) was created with board 
members having the B1/B2 level knowledge of the language. In 2010, the first chairman of the LF Dāvis Stalts was elected elder of the Livonian Union. However, it is too early to judge whether the activities of the organization and the changes in the board of the Livonian Union will improve the prestige of these institutions and restore the use of Livonian as representation and working language.

\section{The Livonian Culture Centre 1994 (Lìvõ Kultūr sidām)}

Since 1994, the Livonian Union has raised questions connected with the historical habitat - the Livonian Coast - as its primary issue. As a result, the Livonian Culture Centre (Livõ Kultür sidām) was founded with, as its main aim, the intention to care for the preservation and promotion of Livonian culture and language, leaving aside any issues connected with economy. Initially, the LCC tried to work and keep records in Livonian, but later, for the same reasons as the Livonian Union, they switched to Latvian. However, public events organized by the LCC with very rare exceptions have always been and are still carried out fully bilingually (in Livonian and Latvian) providing consecutive translation of all the addresses.

\section{The International Livonian Friends' Society 1998}

In 1998, on the initiative of the LCC, the International Livonian Friends' Society was established uniting all the Livonian researchers and interested people world-wide, mainly from Finland, Estonia and Latvia. The record-keeping of this organization is basically in Finnish or Estonian, but the working language often changes due to the international nature of this society. However, the use of Livonian plays an important role in their activities, including public events and meetings, especially in the last five years when it has also been used in the joint LCC and ILFS conferences as the only common language of all participants.

\section{Private business}

New trends can be observed in the use of Livonian in private business. A positive example (probably the only one!) is SIA Kolkasrags who in 2009 created its website in Livonian. This company uses the Livonian language on waste box printing, which is in three languages: Paldies! Tienū! Thank you! These seemingly trivial things reflect their commitment to use Livonian also in business and highlight the colourful Livonian spirit promoting tourism.

Souvenir manufacturer NicePlace also utilizes Livonian in its production: in 2007, they started to issue post-cards picturing a map with the names of the Livonian Coast and to produce T-shirts and cloth bags with prints in Livonian. A bright example is a post-card with the Livonian alphabet this company issued in 2008.

The introduction of Livonian in business operations is very slow, but it can be expected that it could increase gradually, especially in tourism-related companies of the Livonian historical habitat. And this is proved by the fact that in 2010, for example, the Lauku celotājs Association of Rural Tourism compiled the "Latvian-Livonian dictionary: for the elaboration of tourism materials and for the maintenance of reference sources and the Livonian identity"; the dictionary is available on the Internet (Latviešu-Tibiešu 
online). It should be noted that it is not lexicographically polished material; however, it fulfils the functions indicated by the vocabulary builders: "The aim of this dictionary is to provide a translation of the present Latvian words used in everyday life - house names, place names, food, festivities, etc., to be used in tourism materials, territorial marketing and emphasising of the Livonian identity." (Ibid., p. 3)

\section{The Legal bases of the Livonian language}

The rights of Livonian are guaranteed by the State Language Law, adopted in 1999, specifically by three of its sections:

“1) Section 4 - The State shall ensure the maintenance, protection and development of Livonian as the language of the indigenous (autochthonous) population; 2) Section 5 - Any other language used in the Republic of Latvia, except Livonian, shall be regarded, within the meaning of this Law, as a foreign language; 3) Section 18 (4) - Names of places, institutions, public organisations and enterprises (companies) in the Livonian coastal territory, as well as names of events taking place in this territory, shall also be created and used in the Livonian language."

The last section is related mainly to local governments situated in the territory of Northern Courland formerly inhabited by the Livonians, but none of them has ever used this statutory opportunity.

On 14 December 1999 the national long-term target programme "Livonians in Latvia", initiated by the LCC (Livõ Kultūr sidām) and the ILFS, was accepted by the Cabinet of Ministers (for the period from 2008 until 2012). This programme can be legally considered as a mechanism for implementing Clause 4 of the State Language Law during the last decade. However, due to reforms and the economic crisis, which caused a decrease in the state budget, funding for the support of the Livonian programme was significantly reduced (Blumberga 2010).

Livonian is also included in other national programmes and documents (such as the National Culture Policy Guidelines for 2006-2015, the concept of the intangible cultural heritage of Latvia, the 2008-2010 programme implementing Life-long Education Policy Guidelines for 2007-2013, etc.). However, all these undertakings are closely related to the "Livonians in Latvia" programme and anticipate the use of its mechanism.

In 2009, Livonian was included in the Section of National Traditions of the Latvian Cultural Canon as a part of Livonian traditional culture. On the initiative of the International Livonian Friends' Society and the Livonian Culture Centre, the Year 2011 was declared the International Year of the Livonian language and Culture (2011. Tibiešu online).

\section{Livonian in the future}

It is very difficult to predict the future situation of the Livonian language as it is rather unstable and constantly changing. It is clear that the research work and the identification and publication of Livonian materials both in Latvia and abroad will be continued. However, due to specific tendencies of the economic development and state administration, it seems that radical changes in the use of Livonian over the next five or ten years are not to be expected without active and extensive activities, and without any external assistance and funding the Livonian language situation will not improve. 


\section{BIBLIOGRAPHIE}

BLUMBERGA R., 2006, „Lỉbiěsu valodas mācišana Ziemellkurzemes Tibiešu ciemu skolās 20. gadsimta 20. un 30. Gados", Latvijas Universitātes raksti, 2006, 708. sēj., 37.-46. lpp.

BLUMBERGA R., 2010, Lïibieši 19.-21. gadsimtā, MS. 2010

Вогко K., 2000, Livõ kē]. Lỉbiešu valoda. Piški optõbrōntõz. Mazā mācibu grāmata [The Livonian language. The small tutorial], Rỉga: Livu savieniba (Livõd Īt).

ERNŠTREITS V., 2010, Liivi kirjakeele kujunemine. Tartu.

Livõd 2007, Livõd jelāmi. Lïbiešu dzive. The Life of Livonians, Rỉga: Līvõ kultūr sidām; Neputns.

STALTE Kōrli 2011. Jelzi sõnā. Ābēd ja îrgandõks lugdõbdōntõz, Tartu: Jemākīel seL̦tš, Līvõ kultūr sidām.

ŠUVCĀNE V. M. 2006, Lïbieši: vēsturisks apskats, MS. ĪUMSILS, Rīga.

VIITSO Tiit-Rein, ERNŠTREITS Valts 2012, Līvõkīel-ēstikīel-leȚkīel sõnārōntõz. Liivi-eesti-läti sõnaraamat. Lībiešu-igauṇu-latviešu vārdnīca. Tartu/Rīga: Tartu Ülikool, Latviešu valodas aG̣entūra.

\section{Online}

2011. - Tibiešu valodas un kultūras gads [Year 2011 - the year of the Livonian language and culture]. (Last accessed 13.01.2011).

Ernštreits, V., „Lỉbiešu valodas stāvoklis šobrỉd”. (Last accessed 27.09.2010).

Latviešu-Tibiešu vārdnica: tūrisma materiālu izstrādei, uzziņas Tidzeklu un teritorijas iedzivotāju Tibiskās identitātes uzturēšanai [Latvian-Liv dictionary: for the elaboration of tourism materials and for the maintenance of reference sources and the Liv identity of the territory's population]. Lauku celsotājs. Rỉga, 2010, 3. lpp. (Last accessed 14.01.2011).

Lỉbiešu valoda radu saimē [The Liv language among kinsmen]. (Last accessed 15.12.2010).

UNESCO Red Book on Endangered Languages: Europe. (Last accessed 12.12.2010).

Virtmane, V. Pārskats par 2005. gada darbu. (Last accessed 27.09.2010).

\section{NOTES}

1. Hereinafter the language proficiency level is displayed according to the Europass Language Passport. The level of the assessment is generalized.

2. The exact number is unknown, because the conclusion is based on empirical observations or indirect information. Specific and extensive research on the use of the Livonian language and its users has not been currently performed. The last survey was carried out at the end of the 1930s and it covered only the territory inhabited by the Livonians at that time. It was performed by the Livonian Pastor Edgar Valgamaa in 1935-1937 and the results are published in the article "Livonians in the documents and letters" by R. Blumberga. (See: Somijas zinātnieku ekspedicijas pie Tibiešiem. LU Latvijas vēstures institūts. Rīga: Latvijas vēstures institūta apgāds. 2006, 301352. lpp.)

3. Until 2012 - www.livones.lv 
4. Initially the name was The Livonian Culture Society (Livõd Kultūr Īt), now - Liv (Livonian) Union or Livõd İt.

5. To date this festival failed to take place only once - in 2010 .

\section{RÉSUMÉS}

Aujourd'hui, quarante personnes dans le monde sont capables de communiquer en live (au niveau B1 ou à un niveau Europass plus élevé), mais seule la moitié d'entre elles est d'origine live et une seule a le live comme langue maternelle. En étant optimistes, deux cent dix personnes ont un niveau $\mathrm{A} 1$ et $\mathrm{A} 2 . \mathrm{Au} \mathrm{XXI}^{\mathrm{e}}$ siècle, l'amélioration de la situation économique a joué un rôle non négligeable pour permettre l'acquisition de la langue et augmenter le nombre de locuteurs; à cela s'ajoute une promotion active de la langue et de la culture live, qui a permis le lancement de l'apprentissage du live en Lettonie et ailleurs, bien que les animateurs de ces campagnes n'aient pas été d'origine live.

Ces dernières décennies, il a été possible d'apprendre le live dans des cours de langue organisés ad hoc ainsi que dans des camps de vacances; mais cela n'a pas été sans difficultés. Celles-ci tiennent à l'irrégularité de l'enseignement: le financement est insuffisant et l'on manque d'enseignants qualifiés et de programmes d'enseignement adaptés, systématiques. De plus, les personnes intéressées par live et par les Lives sont éparpillées dans toute la Lettonie et dans le monde entier et les écarts dans la maîtrise de la langue sont considérables, ce qui ne permet pas d'organiser l'enseignement sur la base de programmes unifies.

Il n'en reste pas moins que les établissements d'enseignement supérieur ont été actifs dans la diffusion du live, ainsi que dans la recherché sur la langue et dans la publication de matériaux, dont des ouvrages destinés à l'apprentissage de la langue. Il faut ajouter que le nombre de publications de qualité en langue live a été exceptionnellement élevé, particulièrement pendant la dernière décennie. C'est pourquoi il a fallu investir dans l'aménagement linguistique et dans la standardisation du live.

Grâce à la promotion active de la langue et de la culture live dans la dernière décennie, le prestige du live a augmenté et ses possibilités d'utilisation se sont élargies. En plus de garantir son statut, qui est fixé dans la législation, l'État a apporté à la langue live un soutien concret.

Today there are about 40 people worldwide who can communicate (level B1 or higher skills according to Europass) in Livonian, of whom only a half is of Livonian origin and only one is a native speaker. Optimistically judging there are up to $210 \mathrm{~A} 1$ and A2 level speakers. In the 21st century, improvement of the economic situation has played a significant role in enabling language acquisition and an increasing number of speakers, and also an active promotion of Livonian language and culture, which has initiated acquisition of Livonian in Latvia and abroad, however mainly by people who are not of Livonian origin.

During the last decades it was possible to acquire Livonian facultatively in especially organised language courses as well as in summer camps; however the language teaching process and outcome have encountered certain difficulties. These are greatly connected with the irregularity of the teaching process, which is due to insufficient available financing, and also lack of qualified lecturers and adequate, systematic teaching programmes.

Despite the complicated situation in facultative language acquisition, an active acquisition of Livonian has been systematically taking place in higher education institutions, which have also 
actively participated in research into Livonian and publishing Livonian materials, including materials for language studies.

Thanks to active Livonian language and culture promotion within the last decade the prestige of Livonian has increased and its usage possibilities have widened. In addition to the formal status of Livonian, which is fixed in legislation, Livonian has also received practical support from the state.

Mūsdienās lïbiešu valodā visā pasaulē var sazināties ap 40 cilvēku (valodas prasmes līmenis saskaN̦ā ar Europass ir B1 vai augstāks), no kuriem tikai pusei ir lībiešu saknes un tikai vienam lïbiešu valoda ir dzimtā. Optimistiski vērtējot, pasaulē varētu būt ap 210 cilvēku, kuri apguvuši lỉbiešu valodu A1 un A2 līmenī. 21. gadsimtā nozīmīga loma lībiešu valodas apguvē un pratēju skaita pieaugumā ir bijusi ekonomiskās situācijas uzlabojumiem, kā arī aktīvam lïbiešu valodas un kultūras popularizēšanas darbam, kas rosinājis apgūt lïbiešu valodu, gan Latvijā, gan citviet pamatā gan uzrunājot tādus interesentus, kuri paši nav cēlušies no lībiešiem.

Pēdējās desmitgadēs lïbiešu valodu nespeciālistiem ir bijis iespējams apgūt gan īpaši organizētos kursos, gan vasaras nometnēs, tomēr valodas mācību norise un rezultativitāte ir bijusi apgrūtināta. Tas saistīts gan ar neregulāro norisi, kura lielā mērā ir bijusi saistīta ar pieejamo finansējumu, gan kvalificētu pasniedzēju un izstrādātu un secīgu mācību programmu trūkumu. Tāpat negatīva loma valodas apguves procesā bijusi arī lỉbiešu interesentu izkliedētībai gan Latvijā, gan pasaulē, un interesentu dažādajam valodas prasmes līmenim, kas nav țāvis nodrošināt mācības pēc vienotām programmām.

Neraugoties uz sarežG̣īto situāciju lïbiešu valodas fakultatīvās apguves jomā, aktīva lībiešu valodas apguve ir sistemātiski notikusi augstākās izglītības iestādēs, kuras aktīvi iesaistījušās arī lỉbiešu valodas pētniecībā un lỉbiešu valodas materiālu, tostarp mācību palīglīdzekțu publicēšanā. Piebilstams, ka pretēji pieticīgajam valodas apguves procesam, kvalitatīvu publikāciju skaits lỉbiešu valodā, īpaši pēdējā desmitgadē, ir bijis neparasti augsts. Aktīva publikāciju veidošana ir noteikusi arī vajadzību pēc lïbiešu valodas plānošanas un standartizēšanas darba.

Patiecoties aktīvam lībiešu valodas un kultūras popularizēšanas darbam pēdējā desmitgadē uzlabojies arī lỉbiešu valodas prestižs un paplašinājušās tās lietojuma iespējas, tostarp līdztekus formālajam likumos noteiktajam statusam lỉbiešu valoda ieguvusi arī praktisku valstisku atbalstu.

\section{INDEX}

Index chronologique : XXIe siècle (début), XXIe siècle

Keywords : Livonian, mother tongue, Latvia, language planning, language teaching, teachers' training

Index géographique : Ontario, Hiiumaa, Saaremaa, Tartu, Helsinki, Budapest, Courlande, Dundaga, İra (Lielirbe), Irē (Mazirbe), Kūolka (Kolka), Kuoštrõg (Košrags), Mazsalaca, Mustānum (Melnsils), Pāle, Pizā (MiķeL̦tornis), Riga, Sänag (Saunags), Sỉkrõg (Sīkrags), Staicele, Vaid, Ventspils, Vidzeme

disciplines carélien, estonien, finnois, ingrien, live, vepse, vote

Mots-clés : live, langue maternelle, aménagement linguistique, enseignement, formation des maîtres 